\title{
1980'li Yıllarda Türkiye'deki Aydın Bunalımının Türk Tiyatrosuna Yansımaları: Limon Örneği
}

\section{The Reflections of Intellectual Crisis in Turkey in 1980s in Turkish Theatre: The Example of Limon}

\author{
Nazire Akbulut ${ }^{a}$, Arzu Özyön b,* \\ ${ }^{a}$ Prof. Dr., Gazi Üniversitesi, Edebiyat Fakültesi, Batı Dilleri ve Edebiyatları Bölümü, 06560, Ankara/Türkiye. \\ ORCID: 0000-0002-8497-4640 \\ b Öğr. Gör. Dr., Kütahya Dumlupınar Üniversitesi, Yabancı Diller Yüksekokulu, Yabancı Diller Bölümü, 43100, Kütahya/Türkiye. \\ ORCID: 0000-0003-2730-9676
}

\section{MAKALE BILGGISI}

\section{Makale Geçmişi:}

Başvuru tarihi: 11 Mayıs 2018

Düzeltme tarihi: 26 Haziran 2018

Kabul tarihi: 17 Temmuz 2018

\section{Anahtar Kelimeler:}

Memet Baydur

Limon

Aydın Bunalımı

Edebiyat Sosyolojisi

\section{ART ICLE INFO}

\section{Article history:}

Received 11 May 2018

Received in revised form 26 June 2018

Accepted 17 July 2018

\section{Keywords:}

Memet Baydur

Limon

Intellectual Crisis

Literature Sociology

\section{ÖZ}

Bu çalışma Memet Baydur'un Limon adlı oyununu edebiyat sosyolojisi bağlamında ele almakta ve Türkiye'de 1980'lerde yaşanan aydın bunalımının Baydur'un oyunundaki yansımalarını ortaya koymayı amaçlamaktadır. Edebiyat sosyolojisi siyasal, toplumsal ve hatta ekonomik olaylar ile edebiyat; dolayısıyla edebî eserler arasında bir bağ olduğunu iddia eden, böylece edebiyat ile sosyolojiyi aynı çatı altında birleştiren bir inceleme yöntemidir. Buna bağlı olarak çalışma temel olarak 1980'li yıllarda Türkiye'de yaşanan aydın bunalımı sorununun Memet Baydur'un oyunundaki yansımalarının izini sürmekte, Limon adlı oyun aracılığıyla edebiyat sosyolojisinin toplumsal ve siyasal koşulların, edebî eserleri etkilediği yönündeki iddiasını örneklemekte ve doğrulamaktadır.

\section{A B S T R A C T}

This study handles Memet Baydur's play called Limon in the context of literature sociology and aims to reveal the reflections of the intellectual crisis experienced in Turkey in 1980s in Baydur's play. Literature sociology is an examination method which claims that there is a relation between political, social and even economic events and literature; in other words, literary works and thence unites literature and sociology under the same roof. Therefore, the study mainly searches the traces of the reflections of the intellectual crisis experienced in Turkey in 1980s in Memet Baydur's play, through the play called Limon, exemplifies and justifies the claim of literature sociology that social and political circumstances affect the literary works.

\section{Giriş}

Çalışmada yöntem olarak benimsenen edebiyat sosyolojisi, çağın karmaşıklığı ve sorunların tek bir yöntem ile çözülmesinin güçlüğü karşısında edebiyat ve sosyolojinin aynı çatı altında bir araya getirilmesiyle ortaya çıkmış disiplinler arası bir yöntemdir. Edebiyat sosyolojisi, toplum ile edebiyat arasında kopmaz bir bağ olduğu tezinden hareketle sadece edebî eserlerin toplumu etkileyip biçimlendirmekle kalmadığını; aynı zamanda siyasal, toplumsal ve ekonomik koşulların da edebî eserler üzerinde etkili olduğunu savunur. Bu bağlamda Köksal Alver'in (2012: 251) deyimiyle edebiyat sosyolojisi; "edebiyat ile toplumsal olgular arasındaki karşılıklı ilişkileri inceleyerek, edebiyat-toplum ilişkisinin değişik yönlerini, yansımalarını ortaya koymaya çalışmaktadır". Bu alanda yapılmış olan çalışmalara kısaca değinilecek olursa; Emile Durkheim'in Sosyoloji Dersleri (2006), Lucien Goldmann'1n Roman Sosyolojisi (2005), Köksal Alver'in Edebiyat Sosyolojisi

\footnotetext{
* Sorumlu yazar/Corresponding author.

e-posta: arzu.ozyon@dpu.edu.tr
} 
(2012), Ömer Naci Soykan’ın Edebiyat Sosyolojisi- Kuram ve Uygulama (2009) ve Veysel Şahin'in “Sosyolojik Açıdan Ağır Hayatın 'Ağır Roman’ı ve Metin Kaçan” (2016) adlı çalışmaları sayılabilir.

Çalışmada Limon adlı oyunu ele alınan yazar Memet Baydur, gerek eğitim gerekse eşinin işi dolayısıyla dönem dönem yurt dışında yaşama imkânı bulmuş, bu durum da onun, özellikle oyunlarını yazdığı 1980'li yıllarda Türkiye'nin içinde bulunduğu siyasal, toplumsal ve ekonomik koşullara hem içeriden hem de dişarıdan bakabilmesine olanak sağlamıştır. Bu bağlamda Baydur'un, Kamyon, Maskeli Süvari, Limon, Yeşil Papağan Limited gibi birçok oyununda ülkenin içinde bulunduğu koşulların yansımalarını ve yazarın olumsuz koşullar karşısındaki eleştirisini görmek mümkündür.

Memet Baydur'un iki perdelik yedi kişilik ve modern olarak adlandırılabilecek oyunu Limon (1982) 12 Eylül darbesi ile susturulan ve içine kapanarak gerçeklerden kaçan, topluma ve toplumsal sorunlara yabancılaşan aydın kesimin eleştirisini yapar. Cumhur Aslan’a (2011: 37) göre, “12 Mart ve daha sonra 12 Eylül sonrası romanlarda görülen "edilgen" aydın tipi gerçekten düşündürücü bir olgu olarak ayrı bir analizi ve çözümlemeyi gerekli kılmaktadır”. Bu bağlamda bu çalışmada, Memet Baydur'un Limon adlı oyununda 1980'li yıllarda Türk aydınının yaşadığı kimlik bunalımının yansımaları ve bu bunalım sonucu aydınların diş dünyaya yabancılaşması analiz edilecektir. İlk bölümü Aziz ve Muhsin'in evinde (fildişi kulede) geçen ve onlara sırasıyla Necip, Aslı, Berfinaz, Engin ve Sevda'nın katıldığı oyun, bir grup aydının darbenin getirdiği yasaklar nedeniyle kendi kabuklarına çekilmelerini, sürekli içki içip, konudan konuya atlayarak gevezelik etmelerini ve böylece dışarıda olup bitenlere gözlerini kapatıp kulaklarını tıkayarak kayıtsız kalmalarını anlatır. Yazarın oyun içinde oyun tekniğinden faydalandığı ve kişilerin rollerinin sürekli değişerek hayatın aslından bir oyun olduğu fikrinin vurgulandığı Limon'un ikinci bölümü ise Berfinaz'ın evinde geçmekte, bu defa burada toplanan grup havadan sudan konuşmakta, birbiriyle bağlantısız görünen diyaloglar oluşmaktadır. Oyunun sonunda, oyun süresince beklenen Berfinaz'ın yakını Oğuz gelmez. Ancak Sevda ve Engin'in bebeği Limon'un ağlaması ve Aslı'nın oyunun bitimindeki gülümseyişi yine de oyunla ilgili umut vaat eder.

Handan Salta aynı ülkede ve politik sistem içinde yaşamalarına rağmen yazarların aydını farklı şekillerde konumlandırdığını ve aydın kesime karşı tutumlarının farklı olduğunu, bu durumun da yazarların dünya görüşü, bakış açıları ve hayata karşı takındıkları tavrın bir sonucu olduğunu vurgular (2000: 48). Örneğin Oğuz Atay Oyunlarla Yaşayanlar adlı tek tiyatro oyununda romanlarındaki tutumunu devam ettirerek aydın kesimi hayatta tutunacak yeri olmayan bireyler olarak tanımlar (Salta, 2000: 50). Memet Baydur'un, Oğuz Atay'ın hayranı olması da (Gözcü, 2002: 46-47; Baydur, 2002: 64; Şener, 2011: 111) onun Limon adlı oyununda Oğuz Atay’ın yaptığı gibi aydın kesime karşı takındığı eleştirel tavrı doğrular niteliktedir.

"Bireyden topluma giden Oğuz Atay, bireysel yabancılaşmada en büyük etkiyi toplumun kendi öz değerlerine yabancılaşması olarak görür. Yazar, 'Tutunamayanlar', 'Tehlikeli Oyunlar' ve 'Bir Bilim Adamının Romanı' adlı eserlerinde toplumun kendi öz değerlerine nasıl yabancılaştığını vurgular. Turgut Özben'in, toplumun kendi değerlerine yabancılaştığının farkına varması, onun kendi değerlerine yabancılaşan toplumdan ayrışarak kendine özgü bir dünya kurmasına neden olur (Şahin, 2013: 2316).

Yeniçeri (2008: 4), Türkiye'de homojen bir aydın tipi"nin bulunmadığını ve zaman içinde "aydının konumunun ve etkinliğinin değiştiğini dile getirir. Batı toplumunda ortaya çıkan "intellectuel", "literati" ve "les cleres" gibi ayrıntılı kavramların Türkçede tek ve düz "aydınlar" kavramı ile ifade edildiğine dikkat çeken Yeniçeri, aydınların "mesleği bilme olan insan grubu"nu ifade etmek için kullanılan literati gibi sadece bilmekle değil, aynı zamanda yeni bilgi oluşturma ve formüle etme ile de yükümlü olduğunun altını çizer (Şerif Mardin, 1984: 24'den aktaran: Yeniçeri, 2008: 9-10). Toplumsal anlamda düşünüldüğünde de bireyin sadece çok okuması ya da çok bilmesi onu aydın yapmaz, aydın olmak topluma önderlik etmeyi, yol göstermeyi de gerektirir. Faruk Birtek ve Gökhan Ergül'e (1995: 328) göre aydın olmak “ etrafındakini, olağanı, günceli, kabul edileni sorgulamak, anlamak, betimlemek irdelemek; anlatısını mantığı ile oluşturmak, sonra da bu anlatısını, kuramını tersine döndürerek kendi içinde sorgulamaktan geçer”. Kendini, inandıklarını sorgulamak özgür irade gerektirir. Ancak Türk aydını neredeyse her dönemde bir şekilde devlet ile bağlantılı hareket etmek durumunda kalmış ve bu sorgulamayı gerçekleştirememiştir. Adalet Ağaoğlu (1995: 224) Türk aydınının okur-yazarlığını devletin hizmetine verdiğini bu nedenle de aydın değil hizmetkar olduğunu dile getirir. Beşir Ayvazoğlu ise Osmanlı'dan Cumhuriyet'e geçişte aydınların " zafer sarhoşluğu ve bir toplum yapısını değiştirmek gibi olağanüstü bir işe kalkışmanın heyecanıyla, aslında kendilerini içlerinde bir yerde kurt gibi kemiren tereddüdün farkına varamamış, belki de dehşetle farkına vardıkları için, içlerinde bir vicdan azabı gibi sürekli konuşan ikinci benlerini”" susturmuş olduklarını ifade ederek yine aydınların kendilerinden istenenleri sorgulamaktan uzak durduklarını vurgular. Ayrıca, Ayvazoğlu'nun kullandığ 1 'tereddüt', 'ikinci ben' gibi ifadeler aydınların içine düştüğü ikilemi ve kimlik bunalımını göstermesi anlaminda da önemlidir. Memet Baydur'un oyunundaki aydın kesim ise yukarıdaki tanımların tam tersi bir portre çizmekte, topluma ve toplumsal sorunlara yabancılaşmaları ile dikkat çekmektedir. "İnsan, yabancılaşma sonucunda kendine ve kendilik değerleriyle çatışır ve toplumun değer yargılarına öteki olur" (Şahin, 2016: 16). Baydur'un kendisi ise bir aydın hassasiyeti ve yazar sorumluluğu ile içine kapanarak toplumdan kendini soyutlamış bu aydın kesimi eleştirmeyi görev bilir.

Aydın kesimin eleştiriye maruz kalmasına neden olan bu suskunluk ve bunalım hali nedir ve kökleri nereye uzanır? Kuşkusuz aydınların yol gösterici konumlarını yitirmeleri, suskunlaşarak halka ve toplumsal sorunlara yabancılaşmaları sadece onların sorumsuzlukları ile açıklanamaz. Aydın bunalımının temelinde Osmanlı İmparatorluğu'ndan Cumhuriyet'e geçişte devlet müdahalesi ile oluşturulup şekil verilmiş bir aydın sınıfın, kendisine dikte edilenleri yapma zorunluluğu yatmaktadır. Aydın özünde siyasal, toplumsal ve ekonomik sorunlar karşısında toplumu bilinçlendiren, hatta onu yönlendiren kişi olması gerekirken, devlet tarafından farklı dönemlerde, özellikle de darbe dönemlerinde toplumsal kimliğin inşası konusunda bir 
araç olarak kullanılır. Türkiye'de aydın kesimin en önemli özelliklerinden biri Doğu'yu görmezden gelerek Batı'ya yönelmedir. Bu durum ise aydının önderlik etmesi beklenen halk ile arasında bir uçurumun açılmasına, aydının halka ve halkın, toplumun sorunlarına yabancılașmasına neden olur (Yeniçeri, 2008: 18-24). Atilla İlhan'ın (1995: 380) örneği Türk aydını ile halk arasındaki kopukluğu daha somut şekilde gözler önüne serer:

'İngiliz aydını, İngiliz halkından ancak 'derece' itibariyle 'yüksek'te durur, 'mahiyetleri' değişmez: ikisi de Batı'dadırlar, ikisi de Batılı! Türk aydını Türk halkından 'mahiyet' itibarıyla yüksekte duruyor: O, Batı'dadır; Batılı geçinir; halkı ise Doğu'da, en azından Ortadoğu'da, halk kendi tarihini e kültürünü yaşar; aydınlar 'sistem'in ona biçtiği tarih ve kültürü!’.

Burada aslında Türk aydınının özgür iradesi ile hareket etmesinden çok yine kendisine verilen devlete hizmet görevi ya da bir anlamda devlete karşı yerine getirmek durumunda olduğu sorumlulukları vurgulanır. Cumhur Aslan (2011: 37), Türkiye'de aydın kesimin ideolojiye ya da iktidara yakın bir tavır sergilediğini, dolayısıyla da özgür bir şekilde düşünemediğini dile getirerek aynı noktaya dikkat çeker. Daha önce de vurgulandığ 1 üzere, kendilerine adeta bahşedilen görevi kutsal saydıkları için başları dönen aydınlar, kendilerini ayrıcalıklı bir kesim olarak gördüklerinden halk ile aralarında bir kopukluk ve uçurum ortaya çıkar. İlhan Tekeli (1995: 403) bu durumu Atilla İlhan'a göre daha ılımlı bir yaklaşımla "Aydın, ülkesinde aydınlanmayı yaymayı bir misyon olarak yüklendiğinde, misyonunu gerçekleştirme ile halkın seçmelerine saygılı olma konusunda bir ikilemle karşı karşıya kalmaktadır" şeklinde açıklar. Yeniçeri (2008: 20) ise daha keskin bir ifade ile, "Türk aydını şarabı, valsı, operayı, Brüksel'i, Londra'yı, liberalizmi, İngilizceyi, Sosyalizmi ve Decartes'i tanıyınca Türk Halkını ve kültürünü de tanıyacağını sanma hastalığına yakalanmıştır. Bizim aydın diye nitelendirdiğimiz kitlenin tamamına yakını doğuyu batıdan, kırsalı kentten, gecekonduyu saraydan tanımaya ve kurtarmaya kalkmıştır” der. Böylece Türk aydını batının etkisiyle kendi kimliğini kaybetmeye; asıl amacı ve görevinden uzaklaşmaya başlar. Batı'ya ayak uydurma ile özüne dönüp halka yol gösterme arasında bocalayan, gerçekleri dile getirmek yerine susan aydının bunalımı bu ikilemlerden kaynaklanır ki Memet Baydur'un oyununda eleştiri konusu olan tam da bu durumdur. Burada Fromm'un (1995: 53) da ifade ettiği gibi yabancılaşmadan kaynaklanan bir yozlaşma, yabancılaşma sonucunda insani değerlerin çarpıklaşması söz konusudur. Özetlemek gerekirse, devletin kendisine verdiği ülkeyi aydınlatma, modernizmi inşa etme görevi ile halkın seçimleri ve halk kültürü arasında sıkışıp kalan aydın, kısmen modernizmin kendisine verildiği kadarını alıp sorgulamadığı için de bir kimlik bunalım ve yabancılaşma yaşar. Modernleşme akıl yoluyla gerçeği arama tutkusunu insanın ayrılmaz bir parçası olarak görür (Birtek ve Ergül, 1995: 326). Oysa Türk aydını modernizmin bu ilkesini görmezden gelerek uygulamaya koymamıştır. Çağlar Keyder bu durumu kimlik sorununun kaynağı olarak görür.

Öncelikle şimdi orta yaşa dayanmış aydınlar olmak üzere, bir dönemin tüm okuyanları ve düşünenleri devleti modernleşmenin esas getiricisi olarak görmeye alışmışlar. Oysa şimdi ortaya çıkmış ki devlet modernleşmenin sadece kendi kabul edebileceği kısmını üstlenmiş, süreklilik ve öngörülebilirlik kazanan bir hukuk çerçevesini 'devletin yüce ve kutsal menfaatlerine' aykırı bulmuş. Aynı nedenlerle temel hak ve özgürlükleri, birey özerkliğini mutlak gerekli olarak değil, icabında ve zorlanırsa verilebilir, sonradan tekrar geri alınabilir şeyler olarak örmüş. Bütün bu anlatımı da kendini bu konuda sorgulayabilecek herkese yutturmuş. Yani devletin ve devlet elitlerinin stratejisi kısıtlı bir modernleştirme olmuş (Keyder, 1995: 155).

Çok sonraları bu durumun farkına varan Türk aydınının yabancılaşmasının bir nedenini de bu hayal kırıklığında aramak gerek. Modernleşme yolunda önemli bir misyon yüklendiğini düşünerek bu görevi fazlasıyla önemseyen aydın kesim aslında sadece bir araç olarak kullanıldığını ve modernleşmenin sadece kendisine dayatılan kısmını halka iletmek olduğunu ve bu uğurda halk ile ters düştüğünü fark ettiğinde hayal kırıklığına uğrar. Bu hayal kırıklığı onun yabancılaşmasını iki katına çıkarır. Türk aydını artık kendisine de yabancidir.

İlk kez 1980'li yıllarda yazarlığa adım atan Memet Baydur'un hemen her oyununun toplumsal eleştirel yanı ağır basmaktadır. Yurt dışında eğitim alma ve eşinin mesleği dolayısıyla çeşitli ülkelerde yaşama imkânı bulan yazar, Türkiye'deki sosyo-politik ve ekonomik sorunlara içerden ve dışardan olmak üzere iki farklı açıdan bakma şansına sahip olur. Örneğin Kamyon'da (Akbulut ve Özyön, 2016: 7) Türkiye'deki bozuk düzene ve toplumda oluşmaya başlayan tüketim çılgınlığına eleştiride bulunan yazar, Maskeli Süvari'de entelektüel geçinen, ama tarihten kültürden yoksun, kimlik arayışı içinde olan kesimi sorgular. Yazarın Limon adlı oyununun başında da vurguladığı gibi, Oğuz Atay’ın yanı sıra zaman zaman Milan Kundera, Aziz Nesin, William Shakespeare, Harold Pinter gibi daha birçok yazarın etkisi altında kaldığı anlaşılır.

\section{Limon Adlı Oyunda Aydın Bunalımının Yansımaları}

Önceki bölümde de vurgulandığı üzere yazar, Limon adlı oyununda demokrasi sürecinin sekteye uğradığı, bask1, yasak ve sansürün günlük hayatın birer parçası haline geldiği 12 Eylül döneminde aydın kesimin sindirilmesini, kendi dünyasına çekilerek topluma ve toplumsal sorunlara yabancılaşmasını eleştiri konusu olarak ele alır. Oyunun neredeyse daha başlarında Baydur, Berfinaz adlı oyun kişisinin ağzından eleştirisini açık olarak dile getirir:

"ASLI: Ama ağabey...

MUHSIN: (Aslı'yı taklit eder) ... okulum ne olacak?

BERFINAZ: A kızım, düşündüğün şeye bak. Bu zamanda okuyup da ne olacak? İşte Oğuz, işte Aziz, işte Muhsin. Okudular da ne oldu sanki? Bir baltaya sap olamadılar, işleri güçleri laklaklak içip, her şeyle alay etmek. Okumak, tahsil filan eskiden bir işe yarardı. Bir anlamı ve önemi vardı diplomaların. O zamanlar..." (Baydur, 2009: 20).

\section{Aydın Olarak Modern Bireyin Toplumsal Çatışmaları}

1980'lerden beri toplum mühendisleri düzenli olarak para harcayıp okullara gitmek yerine meslek edinip para kazanmanın daha iyi olduğu konusunda telkinlerde 
bulunuyorlar (Özden, 2013: 5). Çünkü okumayıp meslek edinenler okuyanlar gibi sorgulamaz. Kendine sunulan her şeyi kabul eder, para kazanmak ise tek kaygısıdır. Bu nedenle kitaplar yasaklandı ve yakıldı (kitabı değersizleştirmek için; aşağıda da dediği gibi kültürel kimlik oluşturmayı engellemek için) (Kargığlu, 2017), aydınlar üniversitelerden atıld1, üniversiteler özerk yapıya kavuşturulmadı (Özen, 2002) ve en önemlisi gelir düzeyleri hep düşük tutuldu. Tabi bunun yanı sıra dağınık, toplumdan kopuk (klişe), sorumluluk almaktan korkan bir aydın imgesi ortaya çıktı. Berfinaz'ın sözleri de sadece okumakla aydın olunmayacağına ve yeni türeyen sahte aydınların temelsiz yapısına, toplumla alakasız oluşlarına işaret etmektedir. Oyunda belli kişiler üzerinden aydın kesimin farklı olumsuz yanlarına dikkat çekilir. Örneğin Aslı 16. ve 18. sayfalar arasında tam beș kez "Kötü bir şey oldu" der ancak bir türlü anlatacaklarının devamını getiremez. Onun bu hali "susturulmuş" aydın kesimi temsil ettiğinin göstergesidir. Aziz ise aydın kesimin sürekli kendi değerleri ile çatışan, bunalım içindeki ruh halini yansıtır:

"NECİP: Nejdat dediniz de az önce...

\section{MUHSIN: Kim dedi?}

NECIP: Aziz Bey bana hitap ederken Necip yerine Nejdat...

AZİZ: Bağışlayın lütfen, bugünlerde kafam... yüreğim... ve bir iki başka organım pek yorgunlar. İsimleri, yüzleri, elleri, bakışları birbirine karıştırıyorlar” (Baydur, 2009: 15).

\section{Aydın Kimliğin Toplumsal ve Bireysel Yabancılaşması}

Aziz'in Necip kendisini defalarca uyarmasına rağmen ona Nejdat, Nedim, Nahit, Nail gibi farklı isimlerle hitap etmesi onun aklının karışık olması yanında hafızası ile ilgili de bir sıkıntı olduğunu işaret eder. Tıpkı oyunda dinledikleri radyo oyununda vurgulandığ gibi; "RADYO: 'Bir halkı ortadan kaldırmak için hafızasını yok ederek işe başlanır, anlıyor musun?! Kitaplarını, tarihlerini, kültürlerini yok ederler. Başkaları... onlara başka kitaplar yazar, başka bir kültür verir, başka bir tarih uydurur. [...]"” (Baydur, 2009: 2425).Atilla Özkırımlı'nın sözleriyle, "Sürekli arayış içinde olma... Toplumun sürekli bellek kaybına uğraması, uğratılması... Bütünlükten, sentezden yoksunluk... Türk edebiyatçısının, genelde Türk aydınının dramı budur" (1995: 20). Muhsin ise köklerinden koparılmış, yersiz yurtsuz aydının temsilidir: "BERFINAZ: Sürekli yoldadır. Evliya Çelebi mübarek. (Güler) Muhsin... hep gelir, hep gider... (Kendi kendine konuşur gibi) Hiçbir yere kök salamadı gitti. Yerleşik düzen diyorlar ya, işte ona geçemedi bir türlü. Hep gelir, hep gider..." (Baydur, 2009: 68). Muhsin'in kendi deyimiyle o bir "sürgün”, "dışarıda kalmışlardan” dır (Baydur, 2009: 70). "Sürgün” ifadesi Necip'in aydın kesimi tanımlarken kullandığı "öğretim üyesi" ifadesi ile birleştirildiğinde Muhsin'in 1402 sayılı kanunla görevinden uzaklaştırılmış bir akademisyen olduğu sonucuna varılır (Özen, 2002). Sosyolojik bağlamda düşünüldüğünde, bireyin (burada Muhsin'in) kendisini yaşadığı toplum içinde sürgün olarak görmesi toplumsal açıdan bir yabancılaşma yaşadığının göstergesidir. Oyunda Muhsin'in sözleri ile dikkat çekilen bu sürgün olma ve dışarıda kalmışlık hali aslında genel olarak modern çağın tüm aydınları için geçerlidir. "Günümüz Türk aydını bireyi olduğu toplumun dıșına itilmiş, bir 'yalnız ada', hatta 'Heimatlos' durumundadır. $\mathrm{Bu}$, günümüz Türk aydınının değişmesi çok güç trajik yazgısıdır" (Tunalı, 1995: 475). Bunun yanı sıra Muhsin'in bu sürgün, kök salamamış hali akla her biri farklı ülkelerden kopup Fransa'ya göç etmiş absürt tiyatro yazarlarını da getirmektedir. Farklı özelliklere sahip bu bireyleri bir araya getiren ortak nokta hepsinin dışarıdaki ortamdan, yaşananlardan kaçarak içkiye ve gevezeliğe sığınmalarıdır. Muhsin'in Aziz ile yaşadıkları evi "şato" (Baydur, 2009: 14) Aslı'nın ise burayı "eski ve bozulmamış bir mağara” (Baydur, 2009: 17) olarak adlandırması, Aziz'in ise "Dünyadan haberimiz yok" (Baydur, 2009: 16) demesi bu aydın grubunun fildişi kulelerine çekilerek dış dünyadaki sorunlara kayıtsız ve topluma uzak kaldıklarını, yabancılaştıklarını vurgular. Modernizm ile birlikte otoritelerden kurtulup birey haline gelen çağdaş insan ya da bu çalışma bağlamında aydın, "aynı zamanda soyutlanmış, güçsüz, kendisinin dışındaki amaçların bir aracı, kendisine ve başkalarına yabancılaşmış duruma" gelir (Fromm, 2011: 213). Çünkü aslında ne birey gerçek anlamda bireydir ne de bireysellik gerçek anlamda bir bireysellik. Yabancılaşmanın kaynağında yatan temel sorun da budur. Zira günümüzde bireysellik olduğu düşünülen şey aslında “boş bir kabuk”tur ve faşizm bireyin kendisi dışındaki amaçlara boyun eğmesine yol açarak bireyselliğin gerçek anlamda gelişmesini engeller (Fromm, 2011: 213, 216).

Oyun kişileri içinde bulundukları durumun, yabancılaşma ve kayıtsızlığın bilincindedirler zaman zaman bunu dile de getirirler ancak hiçbir şey yapamazlar; ellerinden bir şey gelmez çünkü kendi güçlerine/etkilerine ve bilgileri inançları yoktur:

“AZİZ. Çok içiyoruz gibi geliyor bana...

MUHSIN: Bana da öyle geliyor... Sabah oluyor, öğleye doğru, öğle derken öğleden sonra oluyor mu sana akşamüstü, [...] Yeniden başliyoruz... Hep içiyoruz. İçmesek duramayacağız sanki buralarda. İçerek gicır gıcır nedenler icat ediyoruz kalmak için... sonunda ne kalmış oluyoruz ne de gitmiş... ikisinin ortasında bir yerde içip duruyoruz...

[...]

ASLI: Canım içki içmek istiyor. (Sessizlik) İște böyle olduk. (Muhsin'e) Ölümü öp, doğruyu söyle ...!

MUHSIN: (Oynar) Vallahi de olmaz, billahi de olmaz! daha çok erken canım, şöyle bir güzel tadını çıkaralım...

SEVDA: Neyin tadını?

MUHSIN: Yabancılaşmamızın?” (Baydur, 2009: 41)

Muhsin sürekli içmelerine ve yabancılaşmalarına vurgu yaparken, Aslı toplumdan uzak, soyutlanmış halde bulunduklarına dikkat çeker: "ASLI: İşte böyle. Bir yere tıkıldık ve orada kaldık. Durmadan içiyoruz [...]" (Baydur, 2009: 43). Bu duruma gelmelerinin nedeni ise oyunda satır aralarına serpiştirilmiş olarak verilir:

"NECIP: (Aziz’i duymamış gibidir. Sürdürür konuşmasını) ... yola çıkmak üzereydik. O genç arkadaşla. (Keman) En sevdiğim zamanlar, yola çıkmadan az önceki zamanlardır. [...] Sanki ... sanki bütün yasaklar kaldırılmıştır. Sanki artık "kendim" olabilirim. İyimser düşüncelerimin ortasında, başroldeki ben olacakmışım gibi. Malsız-mülksüz bir ben! 
Ah, yolculuk... ikinci mevkii, müşkül mevkii kaderim benim. Engellenen serüvenciklerim...

[...]

MUHSIN: Hava muhalefet var yahu... Arabalar yokuşları çıkmamakta direniyorlar. İki saat bekledik... evin civarında.

$[\ldots]$

NECIP: (Kendi kendine) Kimsenin kimseyi sorguya çekmediği ülkeler

MUHSIN: Tamam. Sizin votkanızı da şimdi getiriyorum Nedim Bey.

NECiP: (Kendi kendine güler) Olur şey değil doğrusu... Sanki 1967 sonbaharındayım. Sanki hiçbir şey olmamış. [...]" (Baydur, 2009: 33).

Aralarına sonradan yeni tanıdıkları davetsiz bir misafir gibi katılan ve zaman zaman oynanan oyundan çıkma teşebbüsünde bulunan Necip, belki de gerçeklerin en fazla farkında olan kişidir. $\mathrm{Bu}$ nedenle içinde bulundukları gevezeliğe rağmen suskunluk hali ve eylemsizliğin nedeni en sık onun sözlerinde açığa çıkar. Onun için seyahat edebilmesi özgürlük, bu hakkının elinden alınması ise baskı ve yasaklar anlamına gelir. Sözlerinde yer alan "yasaklar" engellenen serüvenler" 12 Eylül döneminin baskıcı yapısını anlatır. Muhsin'in "hava muhalefeti" ifadesi ise bu bağlamda siyasi ortama yapılan bir göndermedir. Bu "şato"ya saklanmış içki ve gevezelik içinde kaybolup gitmiş bu grubun bu halinin nedeni ise baskı ve yasaklar ile susturulmuş, engellenmiş olmalarıdır. Böylece her biri dalgın ya da kafası karışık bu aydın grubu etkisiz hale getirilmiş, hayatın gerçeklerinden kopmuş, diğer bir deyişle içinde yaşadıkları topluma yabancılaşmıştır. $\mathrm{Bu}$ arada Berfinaz'in oyun süresince sözünü ettiği oğlu Oğuz'un 'iki gündür kayı"” olduğu ayrıntısı da 1980'li yıllarda öldürülen, ansızın ortadan kaybolan gazeteci Abdi İpekçi (1979), eski Başbakan Nihat Erim (1980), DİSK başkanı Kemal Türkler (1980) gibi aydın kesimden bireylere yönelik faili meçhul cinayetleri çağrıştırmaktadır. (Gevgilili, 1983: 227; Nebiler, 1996: 1074; Işıklı, 1983: 1834; Birand ve Yıldız, 2012: 132).

Evdeki grubun sürekli içmesinin bir nedeni de onun başına gelebilecekleri düşünmek istemeyişleri olabilir ancak yazarın da sahne notları arasında "çok önemli bir ayrıntı" şeklinde vurguladığ kimse 'çok' sarhoş değildir henüz” (Baydur, 2009: 26). Bu ifade ne kadar içerlerse içsinler olup bitenleri unutamayacaklarının altını çizer. Aziz'in "Mazi kalbimizde yara olmasın. Ona hak ettiği değeri verelim ama, bu arada şimdiki zaman da arada kaynamasın" (Baydur, 2009: 44); (Burada 1968 Gençlik Hareketine, kendilerinin de eylemde bulundukları döneme atıfta bulunmaktadırlar). "Ölülerden söz etmemeliyiz. İhtiyarlardan ve ölülerden söz etmek yasaklanmalı" (Baydur, 2009: 73) şeklindeki sözleri aslında geçmişi/yaşananları, kötü anıları hatırlamak istemediklerini ve şimdiki zamanda takılıp kaldıklarını anlatır. Sürekli içmelerinin bir nedeni de budur. Ancak Muhsin'in cevabı yine yaşadıklarının/geçmişin kolay kolay unutulamayacağını işaret eder: "MUHSİN: Peki ama... anıları ve çağrışımları ne yapacağız?" (Baydur, 2009: 73). Diğerlerinin tersine dışarıda yaşananları/gerçekleri bölük pörçük de olsa sözleriyle yansıtan tek kişi ise Necip'tir. Onun "hâkime hakaretten mahkûmiyet" (Baydur, 2009: 14) aldığını söylemesi de diğer oyun kişilerinden onu ayıran ve onların aksine susmadığını, direndiğini gösteren bir özelliktir.

\section{Aydınların Özgürlük ve Kaçış Sancısı: Oyunlara Yönelim}

Yazarın oyun içinde oyun tekniğinden faydalandığ 1 Limon'un belkemiğini adeta Shakespeare'in (ki adı oyunun başında yazarın etkilendiği isimler arasında geçer) "Bütün dünya bir sahnedir, /Ve bütün erkekler ve kadınlar sadece birer oyuncu; /girerler, çıkarlar. /Bir kişi birçok rolü birden oynar. / $\mathrm{Bu}$ oyun insanın yedi çağıdır." (http://www.gutenberg.org/files/1523 /1523-h/1523-h.htm) sözleri oluşturur. Çünkü oyunda her kapı çalındığında sahne kararır ve her yeniden aydınlandığında oyun kişilerinin farklı rollere büründükleri gözlenir. Oyunun başında Muhsin'in eve getirdiği ve avukat olduğunu söylediği Necip, kapının çalınması ve Aslı'nın gelişi ile Aziz'in dayısı Necip olur; Muhsin ise oğludur. Berfinaz'ın eve geldiği andan itibarense Aslı "evin evde kalmış kızıdır artık" (Baydur, 2009: 19). Necip ise bu defa Aslı'yı istemek için gelmiş muhasebe müdürü rolünü yüklenir. Engin ve Sevda'nın eve gelmesiyle de Necip, bu defa bir şair oluverir. Aslı da Muhsin'in sevgilisi. Oyun kişileri oyun içinde iç içe geçmiş birden çok oyun oynarlar böylece. Tıpkı yeryüzünde doğan, belli görevler üstlenen ve ölenler gibi; tıpkı her sistem değiş̧ikliğinde yeni insanların yeni görevlere geldiği veya getirildiği gibi. Keyfi bir rol üstlenme söz konusudur. $\mathrm{Bu}$ durum Engin'in "Figüran olarak bulunuyoruz nezih tiyatronuzda." (Baydur, 2009: 21) cümlesi ile vurgulandığ 1 gibi yazar tarafından sahne notlarında da açıkça dile getirilir: "Durum değişir giderek. Şimdi çok şey Muhsin'in "kontrolündedir." Bunu ilk anlayan Aziz'dir. Oyunun içindeki oyunun içindeki oyunun içindeki oyuna hemen katılır keyifle. Ansızın hatırlanmış, eski bir çocukluk oyunu oynar gibidirler" (Baydur, 2009: 37). Oyun kişilerinin oynadığ 1 oyunlar, yaşamla oyunun iç içe geçmiş olduğuna dikkat çekmektedir. Ayrıca Fromm'a göre, "Yabancılaşmış kişi, kendi duygu ve düşüncelerini kendi dışındaki bir nesneye aktardığı için, artık kendisi değildir; onda bir 'ben' ya da 'kimlik' duygusu kalmamıştır (1995: 59). Kişilerin kolayca kimlik değiştirebilmeleri ve rolden role geçmeleri de onların kimlik ya da ben duygusu bulunmadığının göstergesidir. Necip'in oyun içinde anlatarak gerçek yaşama, ülkenin sosyo-politik ortamına göndermede bulunduğu; Hristiyanlığın yasak olduğu krallıkta bu din ile alay etmek, eğlenmek amacıyla bir grup oyuncu tarafindan sahnede oynanan vaftiz oyununun gerçeğe dönüştüğü Oyuncuların Masalı (Baydur, 2009: 49) da hayat (ya da gerçek)-oyun dualitesini ve bu iki kavramın iç içe geçmiş olduğunu doğrular niteliktedir. Şener'in (2011: 111), "Oyunlara sığınanlar rollerinde kaybolmaktadırlar" şeklindeki ifadesi de oyun kişilerinin, oyun içinde başka başka rollere bürünerek oyunlar oynadıkları fikrini destekler. 1980'li yılların özellikle siyasal anlamda bir bask1 ve yasaklar dönemi olduğu göz önüne alındı̆̆ında aydın kesimin oyunlara sığınması, onlara bir ölçüde özgür olma ya da diğer bir deyişle kaçma şansı sağlar.

\section{Siyasal ve Toplumsal Yansımalar}

Siyasi göndermeler yanında oyunda toplumsal yaşamdan da yansımalara rastlanmaktadır. 1980'li yıllarda revaçta olan yazın tatil için gidilen kamplardaki lojman hayatı (Baydur, 
2009: 60), tanışıklıklar, komşuluklar gibi toplumsal hayatın renklerinin yanı sıra yine o yıllarda sıç̧a yaşanan yolsuzluk olayları da Muhsin'in sözleri ile oyunda yansımasını bulur: "MUHSINN: (Oyunu sürdürür) [...] Senin karşında kim var biliyor musun? Bir telefonla Doğu'ya sürdürürüm ulan seni! Sen kim oluyorsun bana ceza yazacak? Kırmızı 1 şıkmış! Ulan bize de mi kırmızı 1şık, bize de mi yönetmelik ha?" (Baydur, 2009: 54). Böylece yazar 1980'li y1llarda adam kayırma, görmezden gelme, yakın akrabaların konumundan faydalanma, kamu görevlilerini tehdit etme gibi sıklıkla rastlanan hukuk devletiyle bağdaşmayan toplumsal olgulara da göndermede bulunur. Muhsin'in bu sözleri ayrica İmparatorluk'tan Cumhuriyet'e geçişte Türk aydının içinde bulunduğu ruh halini yansıtan aşağıdaki sözleri anımsatır:

[...] doğrudan katılmamakla beraber, açıkça muhalefet de edemedikleri büyük inkılaplar yaşanırken, hadiselerin önüne geçememekten kaynaklanan bezginliğin tahlil edilmesi zor bir lakaydiye sürüklediği, en ciddi meseleleri bile mizaha bulayarak başka bir kaçış yolu bulan aydınlar da vardır (Ayvazoğlu, 1995: 290).

Baydur'un oyunundaki aydın topluluğu da kendileri dışında gelişen, kontrol edemedikleri bir durum, daha açık bir ifadeyle 12 Eylül darbesi ve onun getirdiği baskı ve yasaklar ile başa çıkamadıkları için bir bezginlik ve lakaytlık hali içindedirler. Konuşmalarında birçok şeyi hatta birbirlerini bile alaya almaları ve sürekli rol değiştirerek oyun oynamaları da onların içinde bulundukları koşullardan uzaklaşma, kaçma isteğinin bir göstergesidir.

Oyun atıflar, göndermeler ve alıntılar açısından son derece zengindir. Örneğin birinci bölümün ortalarında Aslı'nın Necip'i kast ederek Mevlana'nın “Benim sana anlatacağım, ancak senin anlayacağın kadardır” (Baydur, 2009: 35) sözüne yer verdiği görülür. Birkaç sayfa sonra ise kafesteki saka kuşuna isim arayan oyun kişileri çeşitli önerilerde bulunurken Aslı, Aziz Nesin'in Çiçu adlı oyununa atıfta bulunarak kuşun adını Çiçu koymayı teklif eder (Baydur, 2009: 37). Çiçu adlı oyunun ana temasının yalnızlık olduğu düşünülürse, kendilerini toplumdan soyutlamış ve yalnızlık çeken bu grup içinden çıkan bu isim önerisinin anlamı daha iyi kavranmış olur. Necip'in Orhan Veli'nin şiirinden yaptığı alıntı ise tam da gece gündüz içki içen bu gruba yakışır bir dizedir: "İçkiye benzer bir şey var bu havalarda..." (Baydur, 2009: 48). Çalışmanın sınırlılıkları açısından burada tek tek değinilemeyecek kadar alıntı, gönderme barındıran oyunda Shakespeare'in Hamlet'inden (Baydur, 2009: 60) halk arasında bilinen ninnilere (Baydur, 2009: 62) kadar, farklı düzeyde okuyucuya hitap edebilecek alıntı ve göndermeler bulunmaktadır. Bu alıntı ve göndermeler bir yandan bu aydın kesimin bilgi düzeyini/birikimini ortaya koyarken, diğer yandan oyun kişileri üzerinden yazarın birikimini ve oyunun hitap ettiği okuyucu kitlesinin düzeyini de bir dereceye kadar göstermektedir. Mehmet Baydur ayrıca çağının bilinçli kullandı ğ 'metinlerarasılık' olgusuna da vurgu yapmaktadır. $\mathrm{Bu}$ kesimin bilgi birikimine ve eğitim seviyesine işaret eden bir başka unsur onların diyalogları içinde kullandıkları Osmanlıca (Baydur, 2009: 65-66) kelimeler yanında, yabancı dil bilgilerine dikkat çeken Latince, İtalyanca ve Almanca (Baydur, 2009: 26, 28, 33) cümlelerdir.

Oyunda ilk bakışta dikkati çeken teknik bir özellik ise yazarın sahne notlarında yönetmene öneride bulunmasıdır: "Aziz ile Aslı yan yana, biraz şaşkın, biraz duyarlı gözlerle
Necip'i dinlerler. Bu sahneyi 'yazmak' az/biraz cesaret işidir. Yönetene yardımcı bir önerim var. Alabildiğine 'romantik' olmalıdır her şey. Her şey... Elinde kahve ile konyak, Engin girer" (Baydur, 2009: 33). Bu öneri ile yazar bir anlamda yönetmeni yönlendirmektedir.

\section{Aydın Bunalımını Destekleyen Absürt Yansimalar}

Oyunda yer alan birinci mekânda birbiri ile alakasız nesneler bir arada verilmekte bu durum bir kaos ortamı yaratmaktadır: “[...] boş bir kuş kafesi, bir bariton saksafon, eski bir radyo, kurulmuş bir satranç tablası, kapının yanına yaslanmış bir şemsiye- büyük ve siyah-, yanında bir av tüfeği, bir baston, daktilo makinesi, masanın üstünde bir sürü 'extra"” (Baydur, 2009: 13). Bu nesneler tek tek göz önüne alındığında evde yaşayan kişilerin yaşam tarzını yansıtırken, bir bütün olarak ele alındığında evdeki kişilerin kafa karışıklığının bir yansıması olarak yorumlanabileceği gibi -günümüzde çeşitli simgeler kullanarak mesaj göndermek gibi- kuş kafesi, saksafon, radyo, satranç tablası, şemsiye, av tüfeği, baston, daktilo makinesi gibi nesneler birleştirildiğinde yasaklar/hapisler, baskın tonda ortamı belirleme, kamuyu en geniş iletişim aracı ile belirleme/yönlendirme, taktik belirleme, her an sistem dişına çıkma ihtimali, sürekli av peşinde olma, olgun yaşta insanlar (generaller) ve yazarlara getirilen sansür gibi olgulara işaret etmektedir. Evdeki bu alakasız nesnelerin yarattığı karmaşa/kaos, Slawomir (1968: 97-98) Mrozek'in Tango adlı oyunundaki eski bir gelinlik, bir katafalk gibi alakasız ve aynı zamanda absürt eşyaların bir arada bulunduğu evin salonunu akla getirir.

Berfinaz'ın evi olduğu anlaşılan ikinci bölümdeki mekânda ise "[...] Bir sürü eşya. T1kış tıkış. Eski/püskü/ dantelli/tozlu. [...] Bir sürü koltuk. Koltuklardan birinde kafesiyle 'Baykuş' durur" (Baydur, 2009: 57). Berfinaz'ın evinin bu tıka basa eşyalarla dolu hali, Ionesco'nun Yeni Kiracı adlı oyununda kiracının eşyalarla dolup taşan, daralma hissi veren yeni taşındığı evini hatırlatır (2006: 81). Berfinaz'ın evindeki bu manzara ile tıpkı bu eşyalar gibi aydın kesimden insanların da evlere hapsoldukları; eski, tozlu eşyalar gibi bir kenara itilip unutuldukları hissi verilir.

Oyunda zaman konusunda bir belirsizlik vardır: oyunun birinci bölümünde Aslı ve Aziz'in önceden tanıştıkları anlaşılır. İkinci bölümde onların tanıştıkları zamana gidilmiştir yani zamanda geriye dönüş vardır. Tıpkı on yılda bir toplumun karşı karşıya kaldığı askeri darbeler gibi. Muhsin'in daha genç olması, bu geriye gidişi desteklerken; Necip'in on yıl daha yaşlı görünmesi, ilk bölümde nişanlı üniversite öğrencisi bir çift olan Engin ve Sevda'nın evlenip çocuk sahibi olması zaman algısı konusunda bir karışıklığa neden olur. Ancak oyunda rollerin sürekli değiştiği düşünülürse, bu durum belki de oyun kişilerinin ikinci bölümde farklı kimliklere bürünmüş olması ile açıklanabilir.

Batı'daki absürt tiyatro oyunlarının karakter derinliği olmayan yaşları ve isimleri dışında çok fazla özelliği verilmeyen oyun kişilerinin aksine, Baydur'un oyunundaki kişiler karakter özellikleri ile birlikte ayrıntılı olarak betimlenir. Örneğin, "Aziz girer. Kırk yaşlarında, uzun boylu, yorgun yüzlü, uykusuz yaşamış bir adam.” ya da "Necip Bey, altmış yaşlarında, derbeder görüntüsüne rağmen saygı uyandıran, bilgiç ve yavaş bir kişidir" (Baydur, 2009: 13). Sadece karakter özellikleri değil, oyun kişilerinin 
meslekleri de aralarında geçen diyaloglardan öğrenilebilmektedir. Bu betimlemelerde kullanılan "yorgun yüzlü, uykusuz yaşamış bir adam" ya da "derbeder görüntü” gibi ifadelerle aslında yine eğitimli, meslek sahibi entelektüel kesimin yaşadıklarının etkisiyle geldikleri duruma ve yıpranmış olduklarına işaret edilmektedir.

Oyunun birinci bölümünün henüz başında Muhsin ve Necip Bey dışarıda kar yağdığını, trenin hava muhalefetinden dolayı kalkmadığını; (Baydur, 2009: 14) daha sonra ise dışarı çıkıp dönen Muhsin ile Sevda'nın da yine hava muhalefetini haber vermesiyle (Baydur, 2009: 33) oyunda bir anlamda dışarıdaki ortamla ilgili bilgi veren ulak konumundadır.

Absürt tiyatronun Batı'daki örneklerinin umutsuzluk hissi veren sonlarına karşın Baydur'un diyalogların kopukluğuna rağmen bir hikâyeye bağlı kalan oyununun sonunda Engin ve Sevda'nın Limon adlı bebeklerinin ağlaması umut sinyali vermektedir: "Herkes susar. Diyalog bittiği zaman Muhsin'le Aziz sahnenin iki ayrı ucundadır. Baykuş bir an öter, susar. Sessizlik. İçerden Limon'un ağlaması duyulur. Yine sessizlik. Aslı seyirciye bakıp gülümser. Muhsin/Aziz

kımıldamazlar. Uzun süren bir an. Aslı hep gülümser. İçten, mutlu, iyimser. Keman sesi” (Baydur, 2009: 74). Ağlamak normal şartlarda olumsuz bir eylem olmasına rağmen, bunca sessizlik ve suskunluk arasında gelecek neslin habercisi olarak Limon'un ağlaması, diğer bir deyişle anne-babasının da mensubu olduğu aydın kesim gibi susmaması iyiye işarettir. Limon'un ağlamasının ardından Aslı'nın gülümsemesi, ayrıca "içten, mutlu, iyimser" gibi sıfatların kullanılması da oyunun sonunda yansitılan umut duygusunu güçlendirmektedir.

\section{Sonuç}

Bir bütün olarak bakıldığında, Baydur'un oyunu bir yandan biçimsel olarak kimi absürt tiyatro özelliklerini yansıtıp Batı'daki bazı örnekleri çağrıştırırken diğer yandan içine doğduğu toplumun sosyo-politik koşullarının bir resmini çizmesi, özellikle alıntı, gönderme gibi öğeler açısından zenginliği ve oyun içinde oyun tekniği ile özgünlüğü yakalamış bir oyundur.

Tematik bağlamda ele alındığında, yazarın Limon adlı oyununda, 1970'li yıllarda olduğu gibi 1980'li yıllarda da Türk toplumunun öne çıkan sorunlarından biri olan aydın sorununu ele alıp işlemesi, onun bir yazar olarak bu konuda sorumluluk duyması ve bir aydın olarak ülkenin içinde bulunduğu sosyo-politik koşullara duyarlılığı ile açıklanabilir. Yazar oyundaki aydın grubu üzerinden 1980'li yıllarda Türkiye'deki aydın kesimin içinde bulunduğu ruh halini, suskunluğunu ve edilgenliğini; iktidara yakın duruş sergilediğinden özgür iradesi ile düşünüp karar veremeyişini; yine aynı nedenle dış dünyaya ve kendisine yabancılaşmasını konu edinir. Baydur bir yazar ve aydın olarak oyundaki aydın grup gibi susup eli kolu bağlı bir şekilde oturmaz; oyunu aracılığıyla okuyucuyu/izleyiciyi ülkenin durumu ile ilgili bilinçlendirmeye yönelir. Oyun süresince Türk aydını konusunda eleştirel bir tutum benimsediği gözlenen Baydur'un oyununun sonu dikkate alındığında her şeye ve mevcut duruma rağmen bir şeylerin değişeceğine inandığı ve hala gelecekten umutlu olduğu anlaşılır.
$\mathrm{Bu}$ bağlamda ülkenin içinde bulunduğu durumu gözler önüne seren yazarın Limon adlı oyununun, Türkiye'de 1980'li yıllarda yaşanan aydın kesimin kimlik bunalımı ve yabancılaşması temalarını yansıtarak, edebiyat sosyolojisinin, edebiyat ve toplumun birbirinden bağımsız olarak düşünülemeyeceği; sosyo-politik ve hatta ekonomik koşulların edebiyatı ve edebî eserleri etkilediği şeklindeki tezini bir kez daha doğruladığı sonucuna varılmaktadır.

\section{Kaynakça}

Ağaoğlu, A. (1995). Türk Aydını ve Ben Kimim Sorusu. İçinde: Türk Aydını ve Kimlik Sorunu. (Haz. Sabahattin Şen). İstanbul: Bağlam Yayıncılık.

Akbulut, N., \& Özyön, A. (2016). Beckett'in Godot'yu Beklerken Adlı Oyununun Baydur'un Kamyon Adlı Oyununa Yansımaları, VI. Uluslararası Karşılaştırmalı Edebiyat Bilimi Kongresi Bildiri Kitabı, Konya: Selçuk Üniversitesi, 670-679.

Alver, K. (2012). Edebiyat Sosyolojisi ve Hayat. İçinde: Edebiyat Sosyolojisi. Ankara: Hece Yayınları.

Aslan, C. (2011). Türk edebiyatında Aydın Sorunsalı: Oya Baydar'da Süreklilik, Kopuş ve Yeniden Kurgulama, folklor/edebiyat, 17/4(68), 31-51.

Ayvazoğlu, B. (1995). Osmanlı'dan Cumhuriyet'e Geçerken Türk Aydınları. İçinde: Türk Aydını ve Kimlik Sorunu. (Haz. Sabahattin Şen). İstanbul: Bağlam Yayıncılık.

Baydur, M. (2002). Memet Baydur'la Buluşma (İ. Ü. Edebiyat Fakültesi Tiyatro Eleştirmenliği ve Dramaturji Bölümü Etkinliği). İçinde: Elveda Dünya Merhaba Kâinat. (Haz. Sevda Şener, Ayşegül Yüksel, Filiz Elmas), İstanbul: Mitos-Boyut Yayınları.

Baydur, M. (2009). Limon. İçinde: Tiyatro Oyunları, İstanbul: İletişim Yayınları.

Birand, M.A., \& Y1ldı, R. (2012). Son Darbe 28 Şubat. İstanbul: Doğan Egmont Yayıncılık ve Yapımcılık Tic. A.Ş.

Birtek, F., \& Ergül, G. (1995). Postmodern, Türk Aydını ve Frankfurt Okulu: Bir Polemik. İçinde: Türk Aydını ve Kimlik Sorunu. (Haz. Sabahattin Şen). İstanbul: Bağlam Yayıncılık.

Fromm, E. (1995). Çă̆ımızın Özgürlük Sorunu. (çev. Bozkurt Güvenç). Ankara: Gündoğan Yayınları.

Fromm, E. (2011). Özgürlükten Kaçış. (çev. Şemsa Yeğin). İstabnul: Payel Yayınları.

Gevgilili, A. (1983). Türkiye Basını. İçinde: Cumhuriyet Dönemi Türkiye Ansiklopedisi. İstabnul: İletişim Yayınları, (1), 202-228.

Gözcü, S. (2002). İnsanın Gücüne İnanan Oyun Yazar1: Memet Baydur. İçinde: Elveda Dünya Merhaba Kâinat. (Haz. Sevda Şener, Ayşegül Yüksel, Filiz Elmas) İstanbul: Mitos-Boyut Yayınları.

Ionesco, E. (2006). Yeni Kiracı. İçinde: Toplu Oyunları 5. İstanbul:Mitos-Boyut Yayınları.

Işıklı, A. (1983). Cumhuriyet Döneminde Türk Sendikacılığı. İçinde: Cumhuriyet Dönemi Türkiye 
Ansiklopedisi. İstanbul: İletişim Yayınları, (7), 18261838.

İlhan, A. (1995). Aydınların Affedilmez Kopukluğu. İçinde: Türk Aydını ve Kimlik Sorunu. (Haz. Sabahattin Şen). İstanbul: Bağlam Yayıncılık.

Kargıŏglu, İ. (2017). Darbe Döneminde Yasaklanan Kitaplar. (Erişim: 02.04.2018), https://www.pandergi.com/singlepost/2016/10/01/Darbe -D\%C3\%B6neminde-Yasaklanan-Kitaplar

Keyder, Ç. (1995). Kimlik Bunalımı, Aydınlar ve Devlet. İçinde: Türk Aydını ve Kimlik Sorunu. (Haz. Sabahattin Şen). İstanbul: Bağlam Yayıncılık.

Mrozek, S. (1970). Tango. In: Three East European Plays.(çev. Arzu Özyön) (original 1968). England: Penguin Books.

Nebiler, H. (1996). 1980 Sonrası Polis. İçinde: Cumhuriyet Dönemi Türkiye Ansiklopedisi, (14), 1074-1075, İstanbul: İletişim Yayınları.

Özden, Y. (2013). Şimdi Yeni Şeyler Söyleme Zamanı. İçinde: Eğitime Bakış (Ĕgitim-Öğretim ve Bilim Araştırma Dergisi), 9(26), 4-7.

Özen, H. (2002). Entelektüelin Dramı: 12 Eylül'ün Cadı Kazanı. Ankara: İmge Kitabevi.

Özkırımlı, A. (1995). Değer Bunalımı ve Kimliksizleşme. İçinde: Türk Aydını ve Kimlik Sorunu. (Haz. Sabahattin Şen) İstanbul: Bağlam Yayıncılık.

Salta, H. (2000). Çăgdaş Tiyatroda Aydın Sorunu. Altkitap, Kasim.

Shakespeare, W. As You Like It. (çev. Arzu Özyön). The Project Gutenberg.

Şahin, V. (2013). Oğuz Atay'ın Romanlarında Toplumsal Yabancılaşma. Turkish Studies, International Periodical For The Languages, Literature and History of Turkish or Turkic, 8/9, 2313-2322.

Şahin, V. (2016). Sosyolojik Açıdan Ağır Hayatın 'Ağır Roman'1 ve Metin Kaçan. MECMUA Uluslararası Sosyal Bilimler Dergisi, 1(2), 11-28.

Şener, S. (2011). Memet Baydur Tiyatrosu. Tiyatro Araştırmaları Dergisi. 31(1), 109-140.

Tekeli, İ. (1995). Geç Aydınlanan Bir Ülkede Erken Aydınlananların İkilemi ve Popülizm. İçinde: Türk Aydını ve Kimlik Sorunu. (Haz. Sabahattin Şen). İstanbul: Bağlam Yayıncılık.

Tunalı, İ. (1995). Kültür Değerleri ve Türk Aydını. İçinde: Türk Aydını ve Kimlik Sorunu. (Haz. Sabahattin Şen). İstanbul: Bağlam Yayıncılık.

Yeniçeri, Ö. (2008). Dünden Bugüne Türkiye'de Modernite ve Aydın Sorunu. 21. Yüzyıl Dergisi. Ankara: 21. Yüzyıl Türkiye Enstitüsü, (4), 1-24. 